\title{
Pigmented Basal Cell Carcinoma: A Rare Case Report
}

\author{
Anita Moraskar ${ }^{1}$, Shema Shirodkar1, Dheeraj Lambor ${ }^{2}$, Surender Kumar ${ }^{*}$ \\ ${ }^{1}$ North District Hospital, Mapusa, India \\ ${ }^{2}$ Goa Medical College, Bambolim, India \\ Email: *dr.morodia@gmail.com
}

Received 4 February 2016; accepted 10 May 2016; published 13 May 2016

Copyright (C) 2016 by authors and Scientific Research Publishing Inc.

This work is licensed under the Creative Commons Attribution International License (CC BY).

http://creativecommons.org/licenses/by/4.0/

c) (i) Open Access

\begin{abstract}
Basal cell carcinoma is the most common skin cancer mainly caused by prolonged exposure to ultraviolet rays. It is also known as rodent ulcer or basal cell epithelioma. The main mechanism suggested is prolonged exposure to high intensity ultraviolet rays, which causes DNA damage. Pigmented basal cell carcinoma is a rare variety of basal cell carcinoma. Usually, it presents as pigmented nodular mass over the nose or malar region. Other differential diagnoses of this mass, are malignant melanoma and seborrheic keratosis. Treatment of choice is surgical excision with 2 mm of margins.
\end{abstract}

Keywords

Basal Cell Carcinoma, Pigmented Basal Cell Carcinoma, Ultraviolet Radiation

\section{Introduction}

Basal cell carcinoma (BCC) is the most common cancer of the skin in western world in fair skin people. Australia has the world's highest incidence of skin cancer due to ozone depletion and a sunlight overloaded environment [1]. Jacob Arthur in 1827 coined a term "rodent ulcer" for this [2]. Sometimes it is also called as basal cell epithelioma [3]. BCC arises from the layer stratum basale. The most common cause can be chronic exposure to ultraviolet radiation. It is a slow growing malignant tumor, locally aggressive but rarely metastasize [4]. About $80 \%$ are found in the skin of head and neck. Among all variants of BCC, pigmented basal cell carcinoma (PBCC) variety is about $6 \%$ and histopathologically similar to nodular BCC with increased melanization. About $80 \%$ of all basal cell carcinoma in Chinese are pigmented while this subtype is uncommon in white people [5]. $\mathrm{PBCC}$ is relatively rare variety, hence we present this case.

${ }^{*}$ Corresponding author.

How to cite this paper: Moraskar, A., Shirodkar, S., Lambor, D. and Kumar, S. (2016) Pigmented Basal Cell Carcinoma: A Rare Case Report. International Journal of Otolaryngology and Head \& Neck Surgery, 5, 121-124.

http://dx.doi.org/10.4236/ijohns.2016.53020 


\section{Case Report}

A 60-year-old female patient reported to ENT OPD with a complaint of blackish mass on the left side of nose. She noticed the swelling one year back initially small in size, gradually increasing in size over past one year to present size. It was occasionally associated with itching. There was no history of pain. Recently the patient had developed ulcer over the swelling and serous discharge which settled after application of topical cream as prescribed by local physician. There was history of continuous exposure of sun as patient worked in a field.

Clinical examination revealed single blackish elevated lesion situated over left ala of nose extending on to left nasolabial groove, measuring $1.5 \times 1.5 \mathrm{~cm}$ with a well-defined border and a bosselated surface (Figure 1 and Figure 2). There was no evidence of satellite lesions. The mass was firm in consistency and surrounding area was free of any induration. There were no palpable lymph nodes. Clinically, it was suspected to have differential diagnosis of malignant melanoma, basal cell carcinoma.

After detailed investigation, she was planned for excision biopsy under general anaesthesia. The tumour excision was done with $2 \mathrm{~mm}$ surgical margins with dissection plane superficial to perichondrium of lower lateral cartilage, thereby maintaining structural and functional integrity of ala. The resultant defect was primarily closed by local advancement flap by excision of suitable burrow triangles. Post operatively, she developed transient paraesthesia and tightness at the operated site which resolved by 6 weeks. Subsequently wound healed well with acceptable aesthetic outcome (Figure 3).

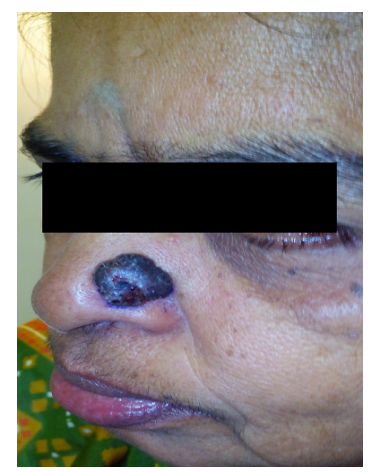

Figure 1. Preop lateral view.

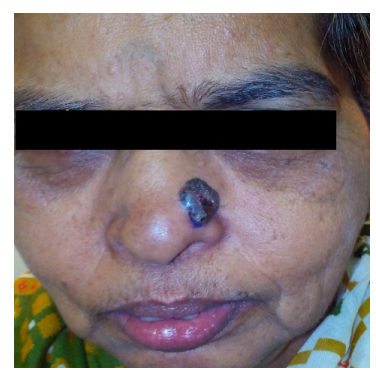

Figure 2. Preop frontal view.

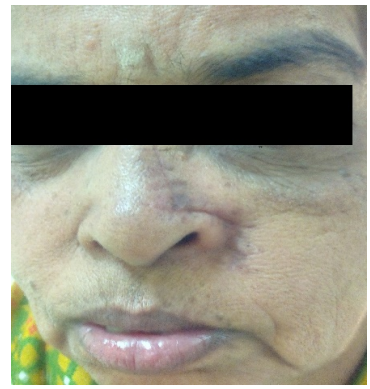

Figure 3. Post op frontal view. 
Histopathology of the specimen revealed findings of pigmented basal cell carcinoma and edges of specimen free from disease.

\section{Discussion}

There are many varieties of BCC like Nodular BCC, PBCC, cystic BCC, superficial BCC, micronodular BCC, morpheaform, and infiltrating BCC of which nodular BCC is the most common variety. In a study of 1039 cases of BCC, Sexton et al. [6] found nodular 218 cases (21\%); superficial 181 cases (17\%); micronodular 151 cases (15\%); infiltrative 77 cases (7\%); and morpheic 11 cases (1\%). Most common age of presentation is fourth to fifth decades of life with male preponderance ( $\mathrm{M}: \mathrm{F}=3: 2)$ [7]. Most common site of occurrence is the middle third of face. Other rare sites reported are areola of nipple by Han Jin Jung et al. [8], subungual by RyuheiOkuyama et al. [9] and eyelids by Lily Koo Lin et al. [10]. Bart RS et al. [11] also noted that pigmented basal cell carcinoma is more common in dark eyed people and very rare in blue eyed people. Although metastasis is very rare, it was reported high in cases of PBCC of nipple-areolar complex due to increased lymphangiogenesis [8]. Histopathologically, there are cells arranged in nests and clusters with palisading of cells at the periphery and in a haphazard manner in the centre. The cells showed hyperchromatic rounded nucleus with little or no cytoplasm (Figure 4). Melanin pigment is seen dispersed among the nests and in the intervening stroma (Figure 5). Our patient is a 60 -year-old female presented with mass over left ala of nose which is a common site for occurrence. Differential diagnoses of mass were malignant melanoma, basal cell carcinoma and seborrheic keratosis which can be differentiated and confirmed by cytology. Cytology of melanoma reveals scattered single cells with occasional loose cohesive groups, which are variable in size, shape and number of nucleus. The nuclei are eccentric with hyperchromatism, often macro nucleoli and atypical mitoses can be seen. Malignant melanoma can be differentiated by advanced immunohistochemistry by using immunomarkers HMB-45 and S-100 [12]. Histopathologically, seborrheic keratosis shows sheets of squamous cells with anucleate squamous and basaloid

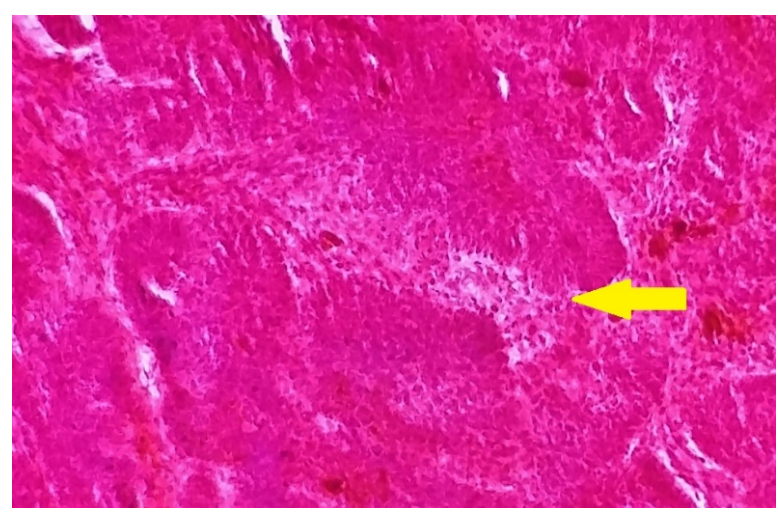

Figure 4. Showing cells arranged in nests and clusters with palisading of cells at the periphery and in a haphazard manner in the center. The cells showed hyperchromatic rounded nucleus with little or no cytoplasm (arrow).

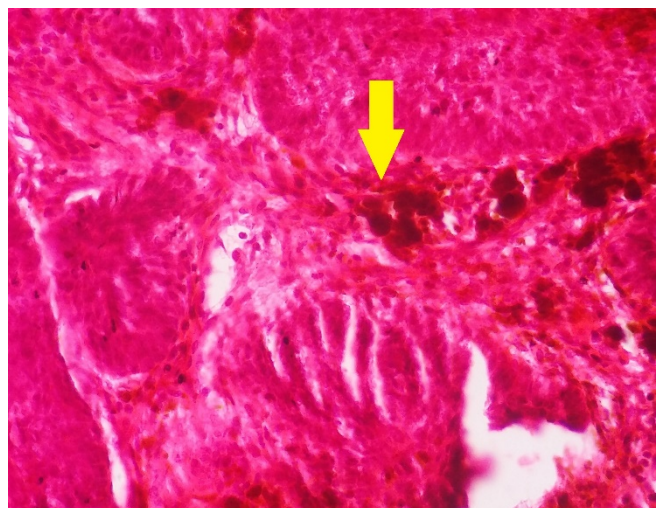

Figure 5. Showing melanin pigment (arrow). 
cells. There is no palisading pattern and no basement membrane matrix [12]. Treatment of choice in PBCC is surgical excision. For larger BCC's with more aggressive growth pattern Mohs Micrographic Surgery (MMS) is recommended [13]. Intralesional injection of interferon alpha is an alternative treatment option [13]. Photodynamic therapy (PDT) is used these days for the treatment of basal-cell carcinoma, which is administered by application of photosensitizers to the target area. Methylaminolevulinate is approved by European Union as a photosensitizer since 2001 .

\section{Conclusion}

PBCC is a rare variety in clinical practice and it is commonly treated as benign nevus by most general physicians. Therefore, a clinical suspicion is necessary while treating elevated pigmented lesions of head and neck. We recommend that pigmented skin lesions in head and neck region with features suspicious of malignancy such as surface irregularity or bleeding should always be excised with adequate surgical margins.

\section{References}

[1] McCarthy, W.H. (2004) The Australian Experience in Sun Protection and Screening for Melanoma. Journal of Surgical Oncology, 86, 236-245. http://dx.doi.org/10.1002/jso.20086

[2] Janjua, O.S. and Qureshi, S.M. (2012) Basal Cell Carcinoma of the Head and Neck Region: An Analysis of 171 Cases. Journal of Skin Cancer, 2012, Article ID: 943472.

[3] Zabbia, G., Gulotta, E., Clemente, D., et al. (2013) Basal Cell Carcinoma Arisen on Rhinophyma: Report of Four Cases. Journal of Case Reports, 3, 299-303. http://dx.doi.org/10.17659/01.2013.0070

[4] Kinci, M., Aslan, S., Markoç, F., Cetin, B. and Cetin, A. (2008) Metastatic Basal Cell Carcinoma. Acta Chirurgica Belgica, 108, 269-272.

[5] Freedberg, I.M., Eisen, A.Z., Wolff, K., Austen, K.F., Goldsmith, L.A. and Katz, S.I. (2003) Fitzpatrick's Dermatology in General Medicine. 6th Edition, McGraw-Hill, New York.

[6] Sexton, M., Jones, D.B. and Maloney, M.E. (1990) Histological Pattern Analysis of Basal Cell Carcinoma. Study of a Series of 1039 Consecutive Neoplasms. Journal of the American Academy of Dermatology, 23, 1118-1126.

[7] Bsoul, S.A., Terezhalmy, G.T. and Moore, W.S. (2004) Basal Cell Carcinoma. Quintessence International, 35, 250251.

[8] Jung, H.J., Jun, J.H., Kim, H.Y., et al. (2011) Pigmented Basal Cell Carcinoma of the Nipple-Areola Complex in an Elderly Woman. Annals of Dermatology, 23, S201-S204. http://dx.doi.org/10.5021/ad.2011.23.S2.S201

[9] Okuyama, R., Watanabe, H., Aiba, S. and Tagami, H. (1987) Subungual Basal Cell Carcinoma in an Elderly Japanese Woman. Journal of the American Academy of Dermatology, 16, 229-233.

[10] Hornblass, A. and Stefano, J.A. (1981) Pigmented Basal Cell Carcinoma of the Eyelids. American Journal of Ophthalmology, 92, 193-196. http://dx.doi.org/10.1016/0002-9394(81)90769-8

[11] Bart, R.S. and Schnall, S. (1973) Eye Color in Darkly Pigmented Basal-Cell Carcinomas and Malignant Melanomas: An Aid in Their Clinical Differentiation. Archives of Dermatology, 107, $206-207$. http://dx.doi.org/10.1001/archderm.1973.01620170018005

[12] Bofin, A.M. and Christensen, E. (2010) In: Gray, W. and Kocjan, G., Eds., Diagnostic Cytopathology, 3rd Edition, Churchill Livingstone, Elsevier, China, 745-746.

[13] Thissen, M.R., Neumann, M.H. and Schouten, L.J. (1999) A Systematic Review of Treatment Modalities for Primary Basal Cell Carcinomas. Archives of Dermatology, 135, 1177-1183. http://dx.doi.org/10.1001/archderm.135.10.1177 